\title{
Future of the Main Important Forest Tree Species in Serbia from the Climate Change Perspective
}

\section{Dejan B. Stojanović ${ }^{1 \Xi}$, Bratislav Matović ${ }^{1}$, Saša Orlović ${ }^{1}$, Aleksandra Kržič ${ }^{2}$, Branislav Trudić ${ }^{1}$, Zoran Galić ${ }^{1}$, Srđan Stojnić ${ }^{1}$, Saša Pekeč ${ }^{1}$}

1 Institute of Lowland Forestry and Environment, University of Novi Sad, Antona Čehova 13, RS-21000 Novi Sad, Serbia

2 Republic Hydrometeorological Service of Serbia/SEEVCCC, Kneza Višeslava 66, RS-11000 Belgrade, Serbia

× Corresponding author: e-mail: dejan.stojanovic@uns.ac.rs

\section{Citation:}

STOJANOVIĆ DB, MATOVIĆ B, ORLOVIĆ S, KRŽIČ A, TRUDIĆ B, GALIĆ Z, STOJNIĆ S, PEKEČ S 2014 Future of the Main Important Forest Tree Species in Serbia from the Climate Change Perspective. South-east Eur for 5 (2): 117-124. DOI: http://dx.doi.org/10.15177/seefor.14-16

\section{Abstract}

Background and Purpose: Climate change is possibly the biggest $21^{\text {st }}$ century challenge for the European forestry. Serbia is also under pressure, since the regions of South Europe and Mediterranean are expected to suffer the most. Main purpose of this study was to predict how distribution of several tree species in Serbia may change in the future.

Materials and Methods: Our study integrates climate change scenarios for the region of Serbia together with the current distribution of forest tree species. Evaluation was performed using forest aridity index which takes into account mean temperatures and sums of precipitation of the critical months during the growing season. Distribution data of the nine most abundant tree species in Serbia (European beech, Turkey oak, Sessile oak, Hungarian oak, Pedunculate oak, Norway spruce, Silver fir, Black and Scots pine) were taken from the National Forest Inventory.

Results: Significant change of bioclimatic niches is expected for the majority of the studied tree species. The most endangered will be Pedunculate oak due to the extreme change of its habitats, while drought prone species (like pines and Hungarian oak) will be less endangered. Sessile oak, Turkey oak, Silver fir, Norway spruce and European beech will be out of their $20^{\text {th }}$ century bioclimatic niches before the end of $21^{\text {st }}$ century according to A2 scenario.

Conclusion: Our results suggest that some of the most important tree species in Serbia (Sessile oak, Turkey oak, Silver fir, Norway spruce and European beech) will be endangered by the end of $21^{\text {st }}$ century. General adaption options and specific measurements for forestry sector have to be made for the region of southeast Europe due to the expected extreme change in climate.

Keywords: climate change impact, adaptation, forest management, bioclimatic niche 


\section{INTRODUCTION}

Change of climate conditions which are observed in past thirty years as well as climate change predictions for future, present a great challenge for forestry [1].

Globally, world's forests influence climate through different ways and their mu-tual interaction is complex [2], although, interaction between forests and climate on the regional and local level is complex, climate as a global phenomenon has a stronger impact on regional forests then vice versa. Negative impacts of climate change on forests are already observed globally and in Europe [3-6]. Also, in Serbia change of realized bioclimatic niches were observed [7-10].

Climate change projections from the year 2000 predict a change of temperature in the range from 2 up to about 6 degrees according to different $\mathrm{CO}_{2}$ scenarios by the end of $21^{\text {st }}$ century $[11,12]$.

By the year 2009 most of the $\mathrm{CO}_{2}$ emission scenarios from the 2000 were exceeded [13], which pointed to quite an uncertain future for the upcoming generations, as well as for forestry. According to this perspective current forest management has to be re-considered in the following years with the aim of adapting to changed climate conditions.

Main purpose of this study was to predict how the distribution of nine tree species in Serbia (European beech, Turkey oak, Sessile oak, Hungarian oak, Pedunculate oak, Norway spruce, Silver fir, Black and Scots pine) may change in the future.

\section{MATERIALS AND METHODS}

Führer et al. [14] proposed a new forest aridity index (FAl) originally designed for yield assessment that is based on the relationships between precipitations and mean monthly temperatures and proved that growth of various species is closely correlated with that index according to a formula:

$$
F A I=\frac{100 * \frac{T V I I+T V I I I}{2}}{P V+P V I+2 * P V I I+P V I I I}
$$

where TVII, TVIII represent mean temperature in July and August and $P V, P V I, P V I I$ and $P V I I I$ the sum of precipitation for May, June, July and August, respectively.

We used that relationship, the climate data and the National Forest Inventory [15] to predict future distribution of forests in Serbia. Climate data for the reference period 19611990 was obtained from the Republic Hydro meteorological Service of Serbia (resolution $90 \times 90 \mathrm{~m}$ ) while the unbiased climate data for A2 scenario was provided from the regional climate model [16] for the periods 20112040, 2041-2070 and 2071-2100 (resolution $25 \times 25 \mathrm{~km},[17])$. According to A2 scenario the temperature in Serbia will rise for about 3.8 degrees by the end of century.

Maps of FAl were created for the periods 1961-1990 (observed climate), 2011-2040 A2, 2041-2070 A2 and 2071-2100 A2 with ArcGIS software.

Graphs of FAI index values for current forest tree species were obtained with SAGA GIS and Statistica 8.0 software.

\section{RESULTS}

Calculations of FAl showed that change in bioclimatic conditions in Serbia may be considerably large (Figure 1), which could, in a long run, have an impact on the current forestry and agriculture practices.

Results suggest that at the end of the century, bioclimatic conditions will be much more arid on the whole territory of Serbia. FAI values below 10 which were present across Serbia in the reference period 1961-1990, will rise to above 15 in some parts of country by the end of the century. The bioclimatic conditions in most of the Vojvodina region in the period 2011-2040 will be equivalent to the conditions in most arid parts in North Banat. 

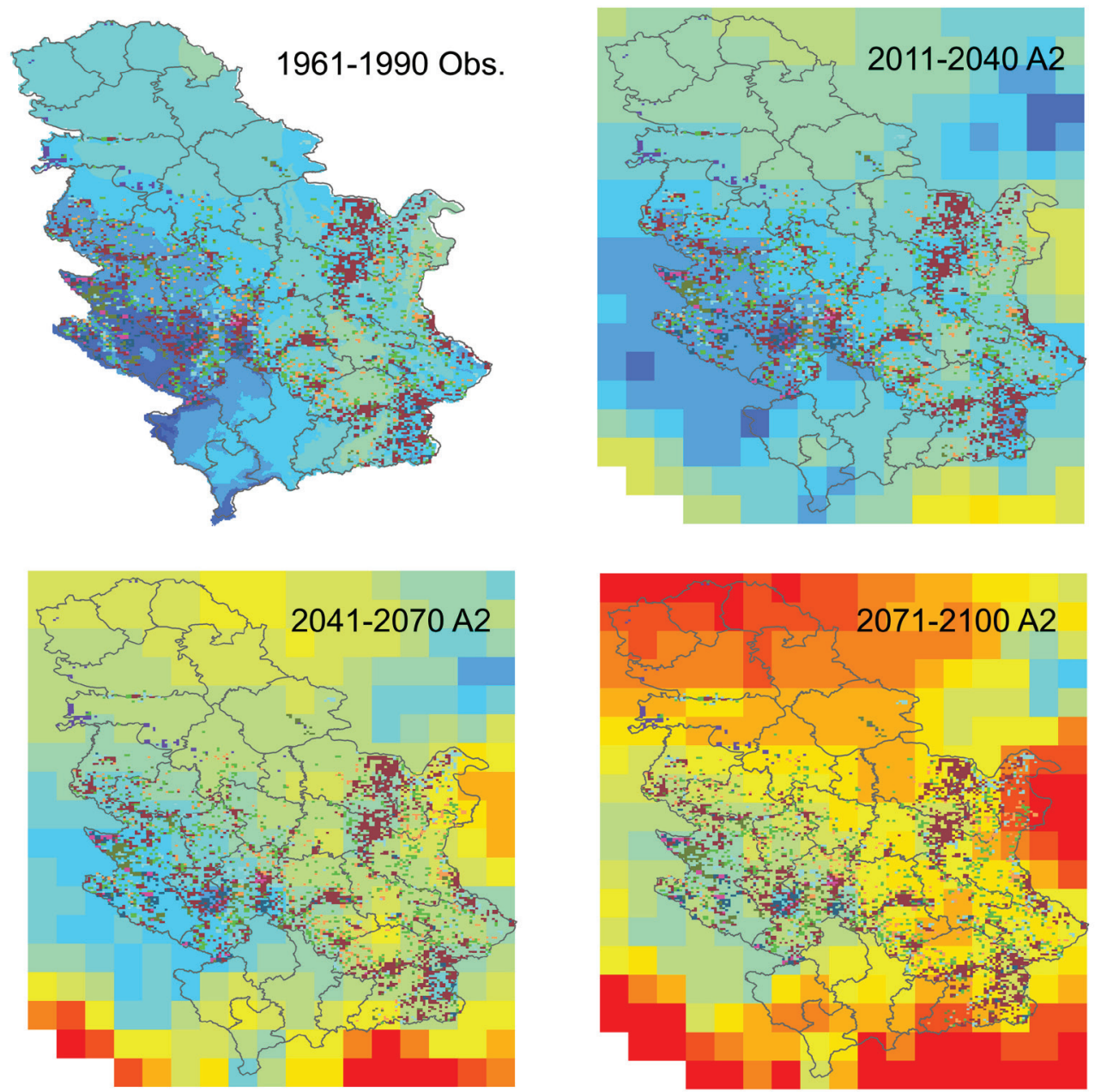

\section{Legend}

\section{Forest trees}

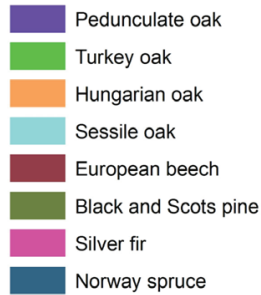

$\mathrm{FAl}$ index categories

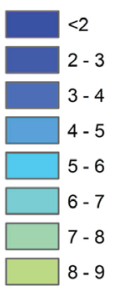

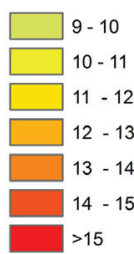

$>15$

FIGURE 1. Maps of Forest Aridity Index (FAI) for four climatic periods (1961-1990 - observed climate, 2011-2040, 2041-2070 and 2071-2100 - predicted climate according to A2 scenario) and indicated distribution of eight forest tree species in Serbia 
Distribution changes have been evaluated for nine species, where Black and Scots pine are allocated in one category as it is recorded in the National Forest Inventory (Table 1).

Distributions of oaks (Table 1, Figures 2, 3, 4 and 5) in the reference period 1961-1990 were within 5.5 and 7.7 of FAl values. In the period 2011-2040 the Hungarian oak will change distribution slightly, while the Pedunculate oak will show a more pronounced change. For future periods, the change of distribution for all oak species will become more drastic.

Beech forests were also taken into consideration (Table 1, Figure 6). According to A2 scenario, the near future will not be too different from the 1961-1990 period, but changes may occur when the climate becomes more arid.
Conifer species (Table 1, Figures 7, 8 and 9) also showed variations in their future distribution as did the broadleaved species. Black pine and Scots pine, as well as other species that survive in dry habitats, will suffer the lowest change in comparison to current habitat conditions. The fact that their distribution in the $20^{\text {th }}$ century partially overlaps with the end of their $21^{\text {st }}$ century distribution seem encouraging for forest managers.

Change of Silver fir distribution will be greater than the change of Norway spruce (Table 1, Figures 8 and 9). The main reason for that is that the niche of spruce is wider in the referent period compared to the niche of fir, which is a result of its better adaptability to drought conditions.

TABLE 1. Mean, maximum and minimum FAl values of current forest distribution in four climatic periods for nine forest tree species

\begin{tabular}{|c|c|c|c|c|c|}
\hline & & $\begin{array}{c}1961-1990 \\
\text { Obs. }\end{array}$ & $\begin{array}{c}2011-2040 \\
\text { A2 }\end{array}$ & $\begin{array}{c}2041-2070 \\
\text { A2 }\end{array}$ & $\begin{array}{c}2071-2100 \\
\text { A2 }\end{array}$ \\
\hline \multirow{3}{*}{ Pedunculate oak } & Mean & 5.8 & 6.7 & 8.2 & 11.9 \\
\hline & Minimum & 4.8 & 5.1 & 7.1 & 9.3 \\
\hline & Maximum & 6.9 & 8.0 & 10.0 & 15.7 \\
\hline \multirow{3}{*}{ Turkey oak } & Mean & 5.7 & 6.2 & 8.0 & 11.0 \\
\hline & Minimum & 4.3 & 5.3 & 6.8 & 9.4 \\
\hline & Maximum & 7.0 & 7.6 & 10.3 & 13.8 \\
\hline \multirow{3}{*}{ Hungarian oak } & Mean & 5.9 & 6.0 & 8.2 & 10.9 \\
\hline & Minimum & 3.6 & 4.3 & 5.6 & 7.7 \\
\hline & Maximum & 7.7 & 8.6 & 12.0 & 16.0 \\
\hline \multirow{3}{*}{ Sessile oak } & Mean & 5.5 & 5.9 & 7.8 & 10.5 \\
\hline & Minimum & 3.3 & 4.3 & 5.6 & 7.7 \\
\hline & Maximum & 7.6 & 8.3 & 10.8 & 15.1 \\
\hline \multirow{3}{*}{ European beech } & Mean & 5.6 & 6.0 & 8.0 & 10.7 \\
\hline & Minimum & 3.5 & 4.3 & 5.6 & 7.8 \\
\hline & Maximum & 7.6 & 8.0 & 10.7 & 14.7 \\
\hline \multirow{3}{*}{ Black and Scots pine } & Mean & 4.7 & 5.2 & 6.9 & 9.5 \\
\hline & Minimum & 3.1 & 4.2 & 5.5 & 7.6 \\
\hline & Maximum & 7.7 & 8.1 & 11.5 & 15.8 \\
\hline \multirow{3}{*}{ Silver fir } & Mean & 3.6 & 4.5 & 6.0 & 8.3 \\
\hline & Minimum & 2.9 & 4.2 & 5.5 & 7.6 \\
\hline & Maximum & 6.1 & 6.4 & 8.9 & 11.9 \\
\hline \multirow{3}{*}{ Norway spruce } & Mean & 4.0 & 4.8 & 6.4 & 8.8 \\
\hline & Minimum & 2.8 & 4.1 & 5.5 & 7.6 \\
\hline & Maximum & 7.4 & 6.9 & 9.4 & 12.7 \\
\hline
\end{tabular}




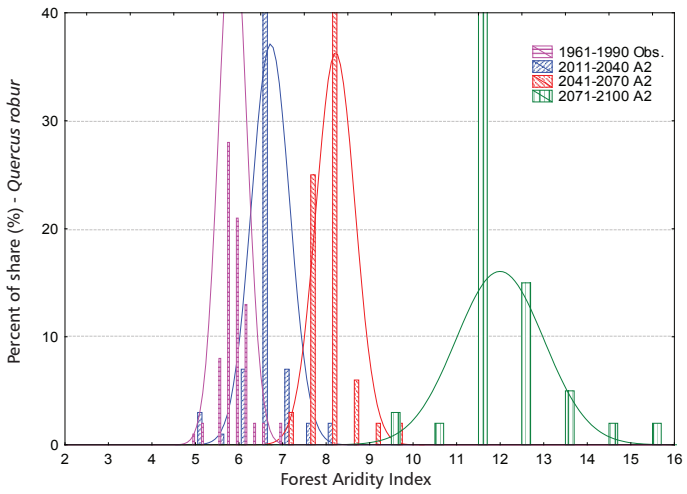

FIGURE 2. Distribution of Pedunculate oak across FAl categories in four climate periods

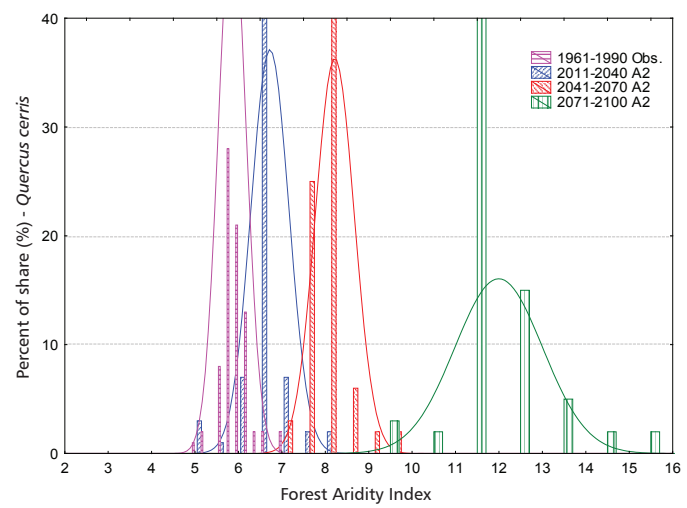

FIGURE 4. Distribution of Turkey oak across FAI categories in four climate periods

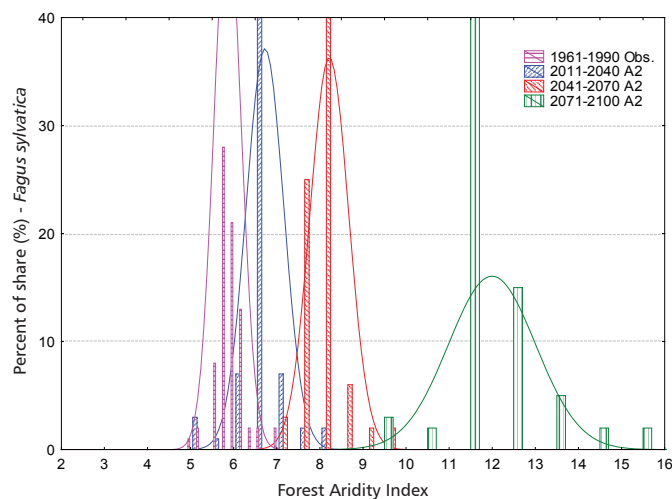

FIGURE 6. Distribution of European beech across FAl categories in four climate periods

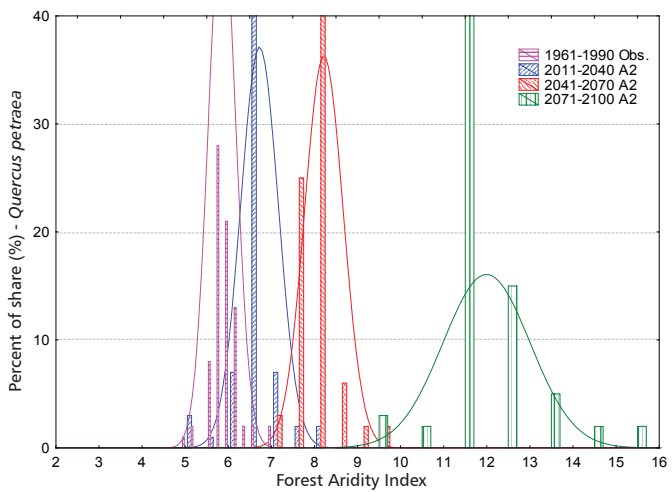

FIGURE 3. Distribution of Sessile oak across FAI categories in four climate periods

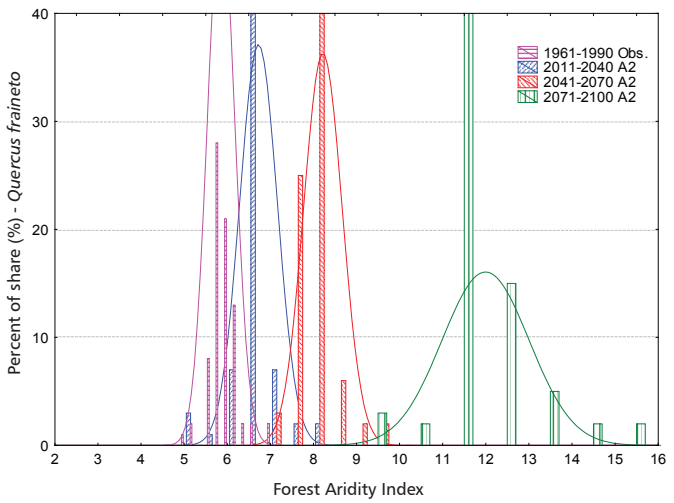

FIGURE 5. Distribution of Hungarian oak across FAl categories in four climate periods

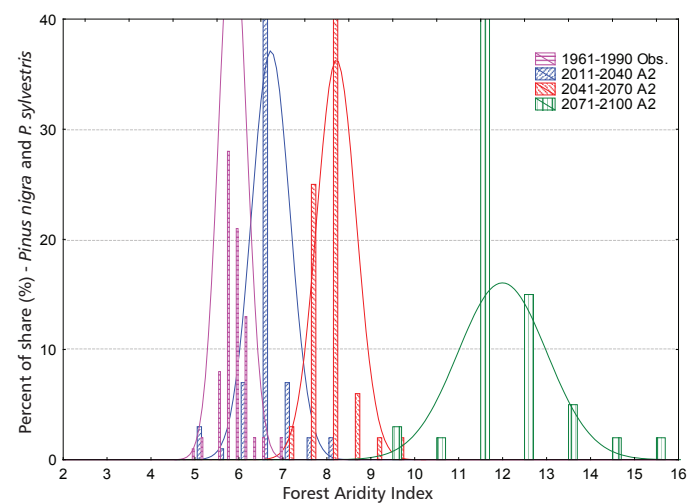

FIGURE 7. Distribution of Black and Scots pines across FAl categories in four climate periods 


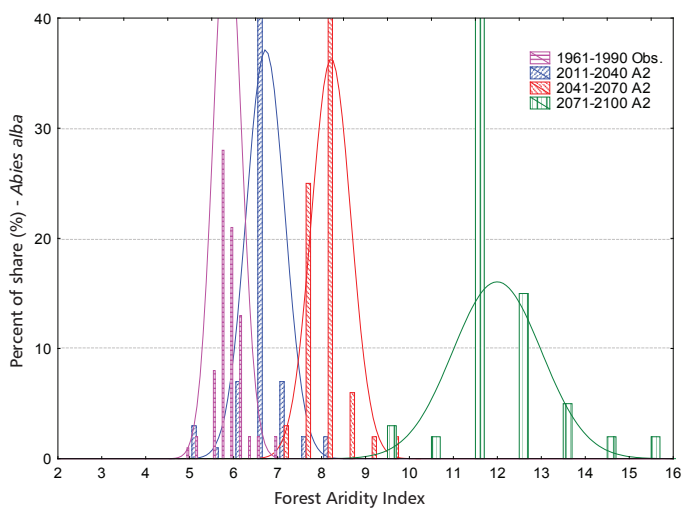

FIGURE 8. Distribution of Silver fir across FAI categories in four climate periods

\section{DISCUSSION}

Similar studies have been carried out in the region. Czúcz et al. [18] found that, according to various climate change scenarios, a decrease of European beech forests in Hungary by the year 2050 can be very high due to the reduction of their bioclimatic niches which are predicted to be between 56 and $99 \%$. Móricz et al. [18] found that by the middle of century only about $35 \%$ of the current beech and $75 \%$ of the sessile oak stands will stay above their current potential distribution limit in the same country.

Stojanović et al. [9] found that by the end of century about $90 \%$ of the European beech in Serbia will be outside of their realized bioclimatic niche and that about half of the stands will be exposed to mass mortality.

Advantage of this approach in comparison to using EQ is that FAl focuses on the climate condition during the growing season.

The change in the seasonal distribution of precipitation is expected, so it can be concluded that FAl can be more sensitive than EQ for this kind of analysis.

It is expected that Pedunculate oak suffers the most from the climate change since it is dependent of groundwater which is experiencing a general decline in Serbia in past years. Additionally, it is situated in lowlands which are the most prone to aridification and

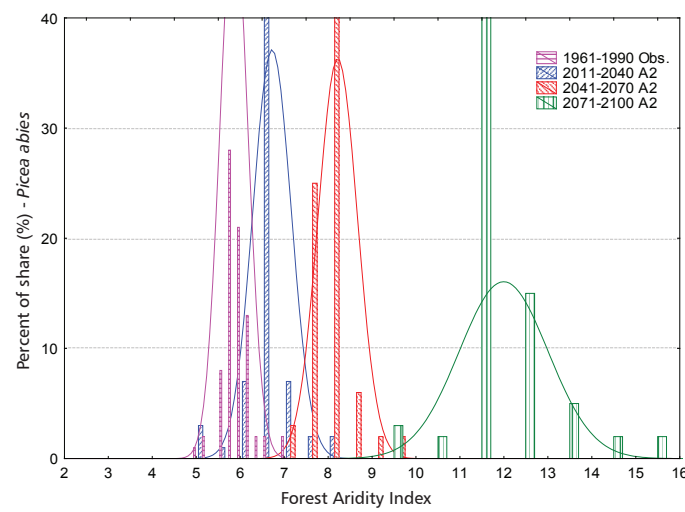

FIGURE 9. Distribution of Norway spruce across FAl categories in four climate periods

temperature increase according to climate change projections [20].

According to this methodological approach, besides Pedunculate oak, Sessile oak, Turkey oak, Silver fir, Norway spruce and European beech will also totally exit their $20^{\text {th }}$ century distribution before the end of the $21^{\text {st }}$ century.

It can be assumed that species, such as Black and Scots pine and Hungarian oak will be the least affected by the climate change. Although some of their current stands will be found in extremely harsh climate conditions in future. It is important to stress that Black pine is more resistant to drought conditions, but these two pine species were evaluated together since they are joined in the National Forest Inventory database.

This study didn't consider the possibility of moving the analyzed species to higher altitudes.

In order to adapt the European forestry to climate change, Lindner et al. [21] emphasized some of the most important measurements which could successfully be applied in the case of Serbia:

1. Additional research

2. Selection of tree species, provenances and genotypes which are more tolerant to expected changed conditions

3. Change of tending and thinning regimes

4. Reduction of biotic and abiotic disturbance risks. 


\section{CONCLUSION}

The most vulnerable tree species to the change of climate among the nine species with the highest abundance in Serbia is Pedunculate oak. Current distribution of species such as the Sessile oak, Turkey oak, Silver fir, Norway spruce and the European beech are under considerable risk due to the climate change, while the Black pine and Hungarian oak are the most resistant in this group.

Our methodological approach, as well as climate projections, suggests that general adaption options and specific measurements for forestry sector have to be made for the region of southeast Europe in the future.

\section{Acknowledgments}

This research was conducted within the project "Studying climate change and its influence on the environment: impacts, adaptation and mitigation" (III 43007) financed by the Ministry of Education, Science and Technological Development of the Republic of Serbia within the framework of integrated and interdisciplinary research for the period 2011-2014.

\section{REFERENCES}

1. ORLOVIĆ S, DREKIĆ M, MATOVIĆ B, POLAKOVIĆPAJNIK L, STEVANOV M, STOJANOVIĆ D, STOJNIĆ S 2014 Serbian Forestry - achievement of millenium goals in the era of climate change and globalization. Bulletin of the Faculty of Forestry University of Belgrade (suppl): 89-112. DOI: http:// dx.doi.org/ 10.2298/GSF14S10890

2. BONAN GB 2008 Forests and climate change: forcings, feedbacks, and the climate benefits of forests. Science 320 (5882): 1444-1449. DOI: http://dx.doi.org/10.1126/science.1155121

3. CIAIS P, REICHSTEIN M, VIOVY N, GRANIER A, OGÉE J, ALLARD V, AUBINET M, BUCHMANN N, et al. 2005 Europe-wide reduction in primary productivity caused by the heat and drought in 2003. Nature 437 (7058): 529-533. DOI: http:// dx.doi.org/10.1038/nature03972

4. LEUZINGER $S$, ZOTZ G, ASSHOFF R, KÖRNER C 2005 Responses of deciduous forest trees to severe drought in Central Europe. Tree Physiol 25 (6): 641-650. DOI: http://dx.doi.org/10.1093/ treephys/25.6.641

5. ALLEN CD, MACALADY AK, CHENCHOUNI $H$, BACHELET D, MCDOWELL N, VENNETIER M, KITZBERGER T, RIGLING A, et al. 2010 A global overview of drought and heat-induced tree mortality reveals emerging climate change risks for forests. Forest Ecol Manag 259 (4): 660-684. DOI: http://dx.doi.org/10.1016/j.foreco.2009.09.001
6. LINDNER $M$, MAROSCHEK $M$, NETHERER $S$, KREMER A, BARBATI A, GARCIA-GONZALO J, SEIDLB R, DELZON S, et al. 2010 Climate change impacts, adaptive capacity, and vulnerability of European forest ecosystems. Forest Ecol Manag 259 (4): 698-709. DOI: http://dx.doi.org/10.1016/j. foreco.2009.09.023

7. STOJANOVIĆ D, MATOVIĆ B, ORLOVIĆ S, KRŽIČ A, ĐURĐEVIĆ V, GALIĆ Z, VUKOVIĆ A, VUJADINOVIĆ M 2012 The use of forest aridity index for the evaluation of climate change impact on beech forests in Serbia. Poplar 189/190: 117-123

8. STOJANOVIĆ D, KRŽIČ A, ORLOVIĆ S, MATOVIĆ B, GALIĆ Z, ĐURĐEVIĆ V 2012 Beech forests under the influence of undergoing climate change. In: Govedar Z, Dukić V (eds) International Scientific Conference: Forestry Science and Practice for the Purpose of Sustainable Development of Forestry - 20 years of the Faculty of Forestry in Banja Luka, Banja Luka, Republic of Srpska/ Bosnia and Herzegovina 1-4 November 2012. Forestry Faculty of University Banja Luka, Banja Luka, Republic of Srpska/ Bosnia and Herzegovina, pp 15

9. STOJANOVIĆ DB, KRŽIČ A, MATOVIĆ B, ORLOVIĆ $S$, DUPUTIE A, DJURDJEVIĆ V, GALIĆ Z, STOJNIĆ $S 2013$ Prediction of the European beech (Fagus sylvatica L) xeric limit using a regional climate model: An example from southeast Europe. Agr Forest Meteorol 176: 94-103. DOI: http://dx.doi. org/10.1016/j.agrformet.2013.03.009 
10. STOJANOVIĆ D 2014 The impact of climate change on carbon sequestration, growth and biodiversity of European beech forests in Serbia (in Serbian). PhD thesis, University of Novi Sad, Faculty of Natural Sciences, Novi Sad, Serbia 239 p

11. NAKICENOVIC N, ALCAMO J, DAVIS G, DE VRIES B, FENHANN J, GAFFIN S, GREGORY K, GRÜBLER A, et al. 2000. Special Report on Emissions Scenarios: Working Group III of the Intergovernmental Panel on Climate Change. Cambridge University Press, Cambridge, United Kingdom, pp 597

12. ALLISON I, BINDOFF NL, BINDSCHADLER RA, COX PM, DE NOBLET N, ENGLAND MH, FRANCIS JE, GRUBER N, et al. 2011 The Copenhagen Diagnosis: Updating the world on the latest climate science. Elsevier, Oxford, United Kingdom, $114 \mathrm{p}$

13. LE QUÉRÉ C, RAUPACH MR, CANADELL JG, MARLAND G 2009 Trends in the sources and sinks of carbon dioxide. Nat Geosci 22: 831-836. DOI: http://dx.doi.org/10.1038/ngeo689

14. FÜHRER E, HORVÁTH L, JAGODICS A, MACHON A, SZABADOS I 2011 Application of new aridity index in Hungarian forestry practice. Quarterly Journal of the Hungarian Meteorological Service 115 (3): 205-216

15. BANKOVIĆ S, MEDAREVIĆ M, PANTIĆ D, PETROVIĆ $N$ (eds) 2009 National Forest Inventory of the Republic of Serbia. Ministry of Agriculture, Forestry and Water Management of the Republic of Serbia, Forest Directorate, Belgrade, Serbia, $238 \mathrm{p}$.

16. DJURDJEVIĆ V, RAJKOVIĆ B 2008 Verification of a coupled atmosphere-ocean model using satellite observations over the Adriatic Sea. Ann Geophys 26 (7): 1935-1954. DOI: http://dx.doi.org/10.5194/ angeo-26-1935-2008
17. RAJKOVIC B, VUJADINOVIC M, VUKOVIC A 2013 Report on revisited climate change scenarios including review on applied statistical method for removing of systematic model errors, with maps of temperature, precipitation and required climate indices changes; Second national communication of the Republic of Serbia under the United Nations framework convention on climate change. MERZ, Belgrade, Serbia

18. CZÚCZ B, GÁLHIDY L, MÁTYÁS C 2011 Present and forecasted xeric climatic limits of beech and sessile oak distribution at low altitudes in Central Europe. Ann For Sci 68 (1): 99-108. DOI: http:// dx.doi.org/10.1007/s13595-011-0011-4

19. MÓRICZ N, RASZTOVITS E, GÁLOS B, BERKI I, EREDICS A, LOIBL W 2013 Modelling the Potential Distribution of Three Climate Zonal Tree Species for Present and Future Climate in Hungary. Acta Silvatica et Lignaria Hungarica 9 (1): 85-96. DOI: http://dx.doi.org/10.2478/aslh-2013-0007

20. KRŽIĆ A, TOŠIĆ I, DJURDJEVIĆ V, VELOVIĆ K, RAJKOVIĆ B 2011 Changes in climate indices for Serbia according to the SRES-A1B and SRES-A2 scenarios. Clim Res 49 (1): 73-86. DOI: http:// dx.doi.org/10.3354/cr01008

21. LINDNER M, GARCIA-GONZALO J, KOLSTRÖM M, GREEN T, REGUERA R, MAROSCHEK M, SEIDL R, LEXER MJ, et al. 2008 Impacts of climate change on European forests and options for adaptation. EFI, BOKU, INRA \& IAFS, 171 p. URL: http:// ec.europa.eu/agriculture/analysis/external/euro forests/full report en.pdf (28 May 2014) 